\title{
THE COMPATIBILITY OF LAND TENURE LAW IN ZANZIBAR WITH ISLAMIC PRINCIPLES: AN ANALYSIS
}

\author{
Abdul-Nasser H. Hikmany* \\ Sharifah Zubaidah Syed Abdul Kader* \\ Ahmad Azam Othman ${ }^{* * *}$
}

\begin{abstract}
Zanzibar land law has been influenced by customary tenure, foreign principles and conventional land regulation. Islamic principles, being the most practiced faith in Zanzibar, are also largely reflected in the regulations and laws of land. This article examines the compatibility of the land tenure laws in Zanzibar with Islamic principles relating to land rights. A comprehensive research has been made through legislation, case laws, textbooks, journal articles, Islamic and Muslim literatures to investigate the compatibility of present land laws in Zanzibar with Islamic principles. This article has come to a conclusion that the Zanzibar land tenure law significantly conforms to Islamic principles save with some challenges facing the land tenure laws. For example, Zanzibar land law, as they presently stand, have provisions contrary to Islamic principles such as permitting interests, land monopoly and land confiscation. Hence, some recommendations are made for the Zanzibar Government to take in reforming the land tenure laws that are conformity with Islamic principles.
\end{abstract}

Keywords: Islamic principles, land law, land tenure, Zanzibar

\footnotetext{
Ph.D. Candidate, Ahmad Ibrahim Kulliyyah of Laws, International Islamic University Malaysia nasser.hamed@live.iium.edu.my.

*** Associate Professor, Ahmad Ibrahim Kulliyyah of Laws, International Islamic University Malaysia.

**** Associate Professor, Ahmad Ibrahim Kulliyyah of Laws, International Islamic University Malaysia.
} 


\title{
KESESUAIAN UNDANG-UNDANG PEMEGANGAN TANAH ZANZIBAR DENGAN PRINSIP ISLAM: SATU ANALISA
}

\begin{abstract}
ABSTRAK
Undang-undang tanah Zanzibar di pengaruhi oleh hukum adat, prinsip undang-undang asing dan peraturan tanah konvensional. Oleh kerana Islam adalah agama yang paling banyak dianuti di Zanzibar, prinsip-prinsip Islam turut terpakai dalam peraturan dan undang-undang tanah. Makalah ini melihat kesesuaian undangundang pemegangan tanah di Zanzibar dengan prinsip-prinsip Islam. Kajian yang terperinci telah dilakukan terhadap undangundang bertulis, kes-kes mahkamah, buku-buku teks, malakah serta penulisan Islam dan Muslim bagi memastikan undang-undang tanah Zanzibar kini adalah selari dengan prinsip-prinsip Islam. Makalah ini menyimpulkan bahawa undang-undang pemegangan tanah Zanzibar adalah selari dengan prinsip Islam. Walaubagaimanapun, terdapat beberapa cabaran yang harus ditangani. Contohnya, terdapat beberapa peruntukan yang bercanggah dengan prinsip tanah Islam kerana ianya membenarkan pengutipan keuntungan berlebihan, monopoli tanah dan rampasan tanah. Oleh itu, beberapa cadangan diutarakan kepada kerajaan Zanzibar bagi memperbaiki sistem undang-undang tanah sediada di Zanzibar agar ia lebih selari dengan prinsip-prinsip Islam.
\end{abstract}

Kata Kunci: Undang-undang Tanah Islam, Undang-undang Tanah Zanzibar, Kesesuaian dengan undang-undang Islam. 


\section{INTRODUCTION}

Zanzibar is a State Government ${ }^{1}$ having its own executive, judiciary and legislative bodies within the United Republic of Tanzania. ${ }^{2}$ Union matters such as foreign affairs and finance are regulated under the Constitution of the United Republic of Tanzania $1977 .^{3}$ Matters on land administration and freedom of worship are considered to be nonunion matters. ${ }^{4}$ These are legislated and regulated by the Government of Zanzibar.

In regard to religious affairs, the Constitution of Zanzibar 1984 stipulates that "the profession of religion, worship and propagation of religion shall be free and a private affair of an individual." 5 The affairs and management of religious bodies are therefore declared under the Constitution of Zanzibar 1984 not "to be part of the activities of the state authority." However, "every person has the right to freedom of thought or conscience, belief or faith and choice in matters of religion, including the freedom to change his religion or faith."

Nevertheless, with the consideration that $95 \%$ of the people of Zanzibar are Muslim, ${ }^{8}$ the Government has established bodies to oversee the affairs of Muslims in Zanzibar. These include the Kadhi's Court Act 1985 in matters of marriage, divorce and inheritance. ${ }^{9}$ The Wakf and Trust Commission Act 2007 to administer wakf properties, trust properties, estate of deceased Muslim, coordinate Hajj activities, distribution of Zakkahs and coordinate national Idd prayers. ${ }^{10}$ Also in the list is the Office of Mufti Act 2001 which, among others, gives 'fat-wa' on any issue to any Islamic question needing to be decided. ${ }^{11}$

Article 2, Constitution of Zanzibar 1984.

Articles 102-107 and 114-115, Constitution of the United Republic of Tanzania 1977.

Article 4 and First Schedule, Constitution of the United Republic of Tanzania 1977.

Article 4(3), Constitution of the United Republic of Tanzania 1977.

Article 19(2), Constitution of Zanzibar 1984.

Ibid.

Article 19(1), Constitution of Zanzibar, 1984.

8 No official figures of religious followers are released in Tanzania. "The Central Intelligence Agency," The World Factbook, accessed June 9, 2016, https://www.cia.gov/library/publications/the-world-factbook/geos/tz.html.

Section 6(1), Kadhi's Court Act 1985.

10 Section 4(1)(a), Wakf and Trust Commission Act 2007.

11 Section 9(1)(a), Office of the Mufti Act 2001. 
Hence, matters of land tenure do not fall under the ambit of any of the preceding bodies. Land tenure laws and regulations in Zanzibar are not therefore required to abide with the Islamic principles.

Zanzibar land laws are, nevertheless, encompassed with numerous Islamic principles, while some challenges contrary to Islam are still observed under the land tenure laws. The land tenure system has additionally been reshaped and is well documented from the revolutionary era to the present times. An emphasis will therefore be given to analyse the pre and post-revolutionary laws which have reliable laws and cases on land tenure. It is from this analysis that salient features will be drawn to show how compatible is the Zanzibar land law with Islamic principles relating to land rights.

\section{COMPATIBILITY OF ZANZIBAR LAND TENURE LAW WITH ISLAMIC PRINCIPLES}

The land tenure legislation in Zanzibar comprises of the Land Tenure Act 1992 as the main land tenure law in Zanzibar. Other land related laws which are analysed in this paper include; the Registered Land Act 1990, Land Adjudication Act 1990 and Land Transfer Act 1994. Also significant is the Wakf and Trust Commission Act 2007 which has close relation to the Zanzibar land tenure. The laws on land tenure are compatible to Islamic principles in regard to public land, dead land and revival of dead land, land allocation or grant, provisional right of occupancy, right of occupancy, refusal of giving private land interests to minerals, water or foreshore, size of grant, collective land, ownership of trees, wakf land, land registration, forfeiture and termination of private land for national interest. However, the laws are faced with challenges in compliance to Islamic principles in relation with the notion of land vesting on the President of Zanzibar, interests and charges, monopoly and hoarding of land and land confiscation.

\section{Public Land}

The concept of public land in Zanzibar permits no one to own land, though the people are given right to usage subject to conditions which 
are stipulated under the laws. ${ }^{12}$ Land is publicly possessed whereas individuals are given right to occupy the land for the use and common benefit of Zanzibar. The Zanzibar Government in this regard is under obligation to regulate allocation, alienation, planning, development, administration and usage of land. ${ }^{13}$

In Islam, the Qur'an emphasises that the earth belongs to Allah. Humankind is given the right to occupy, utilise and enjoy the fruit and take other benefits form the usage of land. ${ }^{14}$ The government can play the role as a trustee and does not in any way purport to hold the land in absolute ownership:

"To Allah belongs all things in the heavens and on earth" 15 and "He it is who has made you vicegerent (to inherent the earth), and has raised you by degree above others, so that $\mathrm{He}$ may try you by means of what He has bestowed on you..."

The right to benefit from land is connected with an amanah (trust) of using the land wisely and also safeguarding it for the future generations. ${ }^{17}$ Thus, man's right to use and benefit from the land is limited and conditional, depending on how he uses his right to benefit from it and respecting the rights of the community and honouring his obligations to it. ${ }^{18}$ The Islamic State reserves the right to take over such individual property whenever it finds that the right is being

12 Section 3, Land Tenure Act 1992. Uses are provided in Section 8, Land Tenure Act 1992: keeping the land in good condition, in cases of agricultural farming in practices of good husbandry, no subdivision unless with the authority's permission and the interest does not include the right to water, mineral or foreshore.

13 Section 3(3), Land Tenure Act 1992.

14 Raj Bhala, Understanding Islamic Law, (Washington: LexisNexis, 2011), 515 516. Siti Mariam Malinumbay, "The Concept of Land Ownership: Islamic Perspective," Buletin Geoinformasi 2, no.2 (1998): 290. See also Fauziah Md. Nor, "Principles of Islamic Land Ownership," in Principles of Malaysian Land Law, Ainul Jaria Maidin et al. (Singapore: LexisNexis, 2008), 602-603.

15 Al-Qur'an, An-Nisa, 4:132.

16 Al-Qur'an, $A n-A m, 6: 165$.

17 Ainul Jaria Maidin and Bashiran Begum Mobarak Ali, "Incorporation of Islamic Principles to the Land Tenure System in West Peninsular Malaysia: Prospect and Progress," Shariah Law Reports 2 (2009): viii.

18 Afzalur Rahman, Readings in Political Philosophy, (London: Seerah Foundation, 1987), 212. 
abused, or is not properly exercised or there is a better use for the community. ${ }^{19}$

The concept of land being publicly owned is in line with Islam as it is God alone who absolutely owns the land and people are entrusted as inheritors. Man being the vicegerent holds property in trust for which he is accountable to Him in accordance with the clearly laid down principles of Islam. ${ }^{20}$ Generally speaking, land is basically under the ownership of Allah Almighty ${ }^{21}$ as ordered according to the teachings of Islam:

Behold, thy Lord said to the angels: "I will create A vicegerent on earth. $^{22}$

The earth belongs to Allah, He gives to his servants as He pleases, and the end is (best) for the righteous. ${ }^{23}$

To Allah belongs all things in the heavens and on earth. And enough is Allah to carry through all affairs. ${ }^{24}$

\section{Dead Land and Revival of Dead Land}

Land in Zanzibar is under the auspices of the government whether occupied or unoccupied. ${ }^{25}$ All land in Zanzibar are therefore not considered as mawat $^{26}$ due to government's ownership or being occupied by people from customary rules or a right of occupancy under the Land Tenure Act 1992. ${ }^{27}$ Nevertheless, the Land Adjudication Act $1990^{28}$ allows revival of mawat land under ihya almawat. This mainly applies to those lands which have been revived before the coming of the Land Tenure Act 1992. The conditions for allowing reviving dead land under the Land Adjudication Act 1990 includes peaceful occupation, opened and uninterrupted occupation




under recognised customary law, for a period of more than twelve years. ${ }^{29}$ The provision of reviving dead land found in the Land Adjudication Act 1990 complies with the Islamic principles of ihya al-mawat:

Whoever rehabilitates barren land becomes its owner. ${ }^{30}$

Whoever reclaims and cultivates dry, barren land will be rewarded by God for the act. So long as men and animals benefit from it $\mathrm{He}$ will record it for him as almsgiving. ${ }^{31}$

He who brings dead land back to life shall himself possess it and he who by force wants to make use of it has no right or title to it at all. $^{32}$

Article 1270 of the Mejelle ${ }^{33}$ defines mawat land as:

...those land which are not the mulk property of anyone, and are not near a town or village, or for their collecting firewood, that is to say, the locality in which the inhabitants of a town or village have a right to cut firewood, and are far from the distant parts of a village or town, that is to say, the sound of a person who has a loud voice cannot be heard from the houses which are extremely limit of the town or village. ${ }^{34}$

To the Shafie jurists, mawat land is simply a dead land, which refers to land that has never been worked on or land that shows no sign of ever being cultivated or developed by human beings. ${ }^{35}$ In Islam, a person can acquire ownership of a mawat land by developing

\section{Ibid.}

30 Al-Tirmidhi and Abu Dawood. See Abdel Hameed Bashir, "Property Rights in Islam" (paper presented at the third Harvard University Forum on Islamic Finance, Cambridge, Massachusetts, 1999).

31 Abdul Rauf Muhammad Al-Munawi, Fayd al-Qadir Sharh al-Jami' al-Saghir, (Beirut: Dar al-Ma'rifah, 1954) 30.

32 Imam Malik, Muwatta. Translation made by Muhammad Rahimuddin, Kitab alRahn, 321. See also Al-Bukhari, Sahih Al-Bukhari, Kitab al-Muzarat, Vol.3.

33 Al-Majalla Al Ahkam Al Adaliyyah, Ottoman Empire.

34 Article 1270, Al-Majalla Al Ahkam Al Adaliyyah.

35 Joseph Schacht, An Introduction to Islamic Law, (Oxford: Oxford University Press, 1982), 142. 
it to life or by way of rehabilitating it. ${ }^{36}$ The Prophet Muhammad (Peace be upon him) granted property rights to anyone who reclaimed land, as long as he had not violated the rights of any former holder of the land:

"Who so cultivates and inhibits a land which does not belong to anyone shall have the best right to it." 37

The nature of revival would differ by place and purpose. $^{38}$ It could mean carrying out irrigation works or digging a well in a rice cultivation field, the planting of trees in a cash crop farm, building a house in a residential area or ploughing the land for sugar plantation and the like. ${ }^{39}$ However, merely digging a ditch or making a hedge or fence around a piece of land, or just pitching a tent upon it does not strictly constitute an ihya. ${ }^{40}$

Anybody who can make dead land cultivable or otherwise useful, he can, with the permission of the authority make improvements therein. The State has the power to dispose of dead land by converting such property into public usages e.g. mosques, Madaris, Inns etc. and other instruction of public welfare. ${ }^{41}$ As for Zanzibar, the Land Tenure Act 1992 permits the Minister responsible for land affairs to make use of any land, including dead land, for the use and common benefit, direct or indirect, of the people of Zanzibar. ${ }^{42}$

Muslim jurists have unanimously agreed that the ownership of the dead land belongs to the person who has rehabilitated or developed the land. This is however, subject to the land being allocated to him by the State through iqta, ${ }^{43}$ There are however strict conditions which must be met for land to be considered ihya'al-mawat. For instance, such land before being revived must not have been used for any useful purposes, should be away from inhabited place. If the land

36 Syed Iqbal Zaheer, An Educational Encylopedia of Islam, (India: East West Educational Tools, 2010), 901.

37 Al-Bukhari, Sahih Al-Bukhari, $5^{\text {th }}$ Edition, Vol.3, 305.

38 Stefano Bianca, Urban Form in the Arab World: Past and Present, (New York: Thames \& Hudson, 2000), 105.

39 Malik bin Anas, Al-Mudawwanah al-Kubra, (Beirut: Dar Sadir, 1958), 195.

40 As-Shafi'e, Kitab Al-Umm, n.d., 77-78.

41 Iqbal, 651.

42 Section 3, Land Tenure Act 1992.

43 Muhammad ibn Idris As-Shafi'e, Kitab Al-Umm, (Cairo: Dar al-Wafa', 2011), 77. See also Fauziah Md. Nor, 619. 
was one time being used, (uncommon in Zanzibar) then it does not fall under ihya' al-mawat. ${ }^{44}$

\section{Land Allocation or Grant}

The Ministry responsible for land affairs is permitted to allocate and grant land to Zanzibar's people for their livelihood in residential, commercial or agriculture areas. ${ }^{45}$ Similarly important is that land laws in Zanzibar give greater emphasis on distribution or grant of land for agricultural purposes ${ }^{46}$.

This system of land allocation or grant is recognised in Islam as iqta'. Iqta' means the act of bestowing or allotting a cut-off piece (qat'iah), it implies the granting of State land to individuals at different times. ${ }^{47}$ The Prophet Muhammad (Peace be upon him) granted land throughout his lifetime, e.g. he gave a piece of land in Bi'rul Qais to Ali ib Abu Talib, ${ }^{48}$ in valley Aqiq to Bilal ibn Harith, in Bani Nadir to Abu Bakr. ${ }^{49}$ Apart from the Prophet, the Caliphs also granted lands for development, strength and winning over tribes in Jurf and Qinat to az-Zubair by Abu Bakr, by Umar to Sa'ad ibn Abu Waqas, 'Abdullah ibn Mas'uud, Usamah and Ibn Zaid ${ }^{50}$ The land was granted for housing, farming and gardening where the grantees had right to use or transfer the title. ${ }^{51}$ Some important elements governing iqta' land (land allocation and grants) includes:

1. Tamlik: Refers to a claim for dead land in which a private estate is linked with the right of ownership. Only dead,

\footnotetext{
44 "Islamic Balance Between This Life and The Hereafter," Ragheb El-Segany, accessed May 22, 2016, http://www.onislam.net/english/reading-islam/researchstudies/islamic-thought/452455-islamic-balance-between-this-life-a-thehereafter.html

45 Sections 30 and 32, Land Tenure Act 1992.

46 Land Distribution Decree 1966 which permitted the Three Acre Plots for agricultural purposes. See also Sections 42, 42A, 44, 45 and 69 (1) (d), Land Tenure Act 1992.

47 Iqbal, 657.

48 Siraj Sait, A Training Course on Land, Property and Housing Rights in the Muslim World, (Nairobi: UNHABITAT, 2010), 186.

49 Raj Bhala, 515-516, Siti Mariam Malinumbay, 290 and Fauziah Md. Nor, 515516.

50 Ziaul Haque, Landlord and Peasant in Early Islam, (Islamabad: Islamic Research Institute, 1977).

51 Fauziah Md. Nor, 611.
} 
developed and mining (ma'adin) land can be granted as iqta' tamlik. ${ }^{52}$

2. Amir (cultivated or developed land): Land which belongs to Baitul Mal (Public treasury) in which a ruler has no authority to grant the land on iqta ${ }^{53}$ For instance, land that is not owned by any person but is used for the common benefit of all the residents of a locality or from which certain things of common use like salt, kerosene oil, petrol etc. is being extracted. Such property shall for ever remain open for public use (like "Wakf") under the supervision of the Muslim Government. Neither any Ruler nor Amir can become himself the owner of such land no one else can be owner thereof. ${ }^{54}$

3. Irfaq: Refers to the allocation of certain portion of lands for public places e.g. a mosque, road, market or business etc. $^{55}$

4. Ownership: Shafie School is of the view that only the right of possession is conferred in the first phase to the grantee and upgrading to full ownership is upon developing the dead land within three years of taking possession of the land. ${ }^{56}$

5. Limitation: Majority of the Muslim jurists unanimously agree that the land can be allocated to an individual depending on the ability of utilisation or cultivation. ${ }^{57}$

Among the principles of iqta and irfaq that the Land Tenure Act 1992 complies with include; the holder of a right of occupancy having an exclusive right to occupy and use the land which comprises his right. ${ }^{58}$ The other condition is that:

...no interest may be held by any individual which has an area of less than three fifths of a hectare provided that parcels which are

52 Jeanne Mckay, Integrating Religion Within Conservation: Islamic Beliefs and Sumatran Forest Management, (Canterbury: Durrell Institute of Conservation and Ecology, 2013), 15.

53 Mohammad Hashim Kamali, Shariyah Law: An Introduction, (Oxford: One World Publications, 2008), 252.

54 Iqbal, 651.

55 Afzalur Rahman, Economic Doctrines of Islam, (Lahore: Islamic Publication Ltd., 1990).

56 "Land Ownership in Islam," accessed June 9, 2016, http://slideshare.net.

57 Abu 'Ubayd al-Qasim ibn Sallam, Kitab Al-Amwal, (Cairo: Maktabah alKulliyyah al-Azhariyyah, 1968), 290.

58 Section 8(1)(c), Land Tenure Act 1992. 
less than three fifty of a hectare in area before they are granted and registered for the first time can be maintained at that size, but once the land is registered and entered on the cadastral index map no parcel may be subdivided so that the area is less than three fifths of a hectare; ${ }^{59}$

Also in the list is that the interest does not include the right to water, mineral or foreshore ${ }^{60}$ each grant is made provisionally for a two year period during which time no legal rights shall exist ${ }^{61}$ and final assignment of the grant shall be made through the issuance of an order of grant after the fulfillment of all covenants and conditions laid, down in the document of grant have been satisfied. ${ }^{62}$

\section{Provisional Right of Occupancy}

The Land Tenure Act 1992 is very clear on the condition for a grant of land to Zanzibar's people that it has to be utilised within two years. This is known as provisional grant in which the grantee has only possessory rights and proprietary rights to transfer ownership during the provisional period is prohibited. ${ }^{6}$

The same idea of insisting usage during a grant is recognised in Islam as from the views of Shafie, Hanafi and Abu Yusuf. All of these jurists are of the view that iqta' (grant) will not commence until the grantee utilises or develops the land. ${ }^{64}$ The Prophet is reported to have stated that "If anyone has land, he should cultivate it or lend it [free of charge] to his brother for cultivation, or otherwise release it from his ownership". ${ }^{65}$

The underlying theme of the provisional right of occupancy is that the owner is required to use his land in ways that benefit him while not hurting the general interest of society. Any inefficient use of land is in violation of the objectives (maqasid Shari'ah). If the proprietor proves his inability to use it properly, he forfeits his ownership rights. Under such conditions, the State is fully justified in

Section 8(2)(d), Land Tenure Act 1992.

Section 8(2)(g), Land Tenure Act 1992.

Section 33(1), Land Tenure Act 1992.

Section 33(3), Land Tenure Act 1992.

Sections 33, 39 (2), 42 (2) and 42 (3), Land Tenure Act 1992.

64 Nicolas Agnides, An Introduction to Mohamedan Law and A Bibliography, (Lahore: Sang-E-Meel Publication, 1961) 505.

65 Reported by Ahmad and Muslim.
} 
withdrawing the rights of usage of that land in order to protect it from the misuses of its owner. ${ }^{66}$

Some of the Jurists are of the view that utilisation of the land should be made within three years. Hameed states that no right of ownership will be claimed on the land if the owner does not reasonably exploit it after three years of possession. ${ }^{67}$ Mannan is also in the same view that there should be a limit of three years to bring the land into actual use. ${ }^{68}$ Ziyad on the other hand seems to agree with the two years which have been stipulated under the Land Tenure Act 1992. ${ }^{69}$ Shafie School, however, has not fixed any duration, the condition he has put forward is that the government has to remind the possessor to utilise the land from time to time. ${ }^{70}$

\section{Right of Occupancy}

The wordings of "occupancy" ${ }^{71}$ and "interest" ${ }^{\text {, }}$ linked to the right of holding land in Zanzibar does not permit ownership of land, rather than the right of occupying any development or fruits derived from land to the person having an interest on the land. This concept of a right of occupancy is also in line with Islamic principles as the ultimate and absolute ownership belongs to Allah. ${ }^{73}$ The Land Tenure Act 1992 consents to occupying the land by the people for the purpose of making use the same. ${ }^{74}$ Land usage, rights and interest in Zanzibar are therefore compatible to the concept of trusteeship in Islam. A man in Islam is a trustee as he is being given power to execute the trust according to the wishes of the Creator of the trust.

66 Hanifa (2002) cited by Dato' Shahran Laili Haji Abdul Munib, "Corporate Governance in Islamic Perspectives," (paper presented at the Fifth International Islamic Finance Conference, Kuala Lumpur, September 3-4, 2007).

67 Bashir, 81.

68 Muhammad Abdul Mannan, Islamic Economics: Theory and Practice, (Cambridge: Hodder and Stoughton - The Islamic Academy, 1986), 99-100.

69 Fauziah Md. Nor, 606.

70 Abu 'Ubayd al-Qasim ibn Sallam, 290.

71 Section 7, Land Tenure Act 1992.

72 Section 8(1)(d), Land Tenure Act 1992.

73 Sayyid Abu A'la Mawdudi, in First Principles of Islamic Economics, ed. Khurshid Ahmad, (London Kube Publishing Ltd., 2013), 122.

74 Sections 7-10, Land Tenure Act 1992. 
Man is bound to fulfill this trust by using land according to the laws of Allah and not contrary to it. ${ }^{75}$

The Qur-an recognises private land ownership in the verse relating to the permissibility of transactions:

"O ye who believe! Eat not up your property among yourselves in vanities. But let there be amongst you traffic and trade by mutual goodwill...,76

The protection of property is also one of the objectives of the Shari'ah (Maqasid Al Shariah) to be safeguarded by the Islamic State. However, private ownership in Islam is not absolute. It is limited to sharing one's wealth with the poor, underprivileged and the marginalized in a society for achieving social justice. ${ }^{77}$ The State also reserves the right to acquire private lands when it is left idle by the landholder and in the case of the land being needed for the public interest.

A right of occupancy in Zanzibar corresponds to private ownership in Islam as property (including land) is recognised:

That ye believe in Allah and His Messenger, and that ye strive (your utmost) in the cause of Allah, with your property and your persons, That will be the best for you, if ye but knew. ${ }^{78}$

And He it is who has made you vicegerent (to inherit the earth), and has raised you by degree above others, so that He may try you by means of what He has bestowed on you. ${ }^{79}$

Believe in Allah and His Messenger and spend of what whereof he has made you Vicegerents, and those of you who believe and expend shall have a great reward. ${ }^{80}$

75 Muhammad Akram Khan, "The Role of Government in the Economy," The American Journal of Islamic Social Sciences, 14(2) (1997): 160.

76 Qur'an, An-Nisa, 4:29.

77 Sayyid Qutb, Social Justice in Islam, (Lahore: Islamic Publications International, 2000). See also Fauziah Md. Nor, 604.

78 Al-Qur'an, Al-Safat, 37:11.

79 Al-Qur'an, An-Am, 6:165.

80 Al-Qur'an, Al-Hadid, 57:7. 
It is $\mathrm{He}$ who has made the earth manageable for you, so traverse you through its tracts and enjoy the sustenance which he furnishes; but unto Him is the resurrection. ${ }^{81}$

\section{No Interest to Minerals, Water or Foreshore}

The right of occupancy exists in Zanzibar with the condition that interest shall not include the right to water, mineral or foreshore. ${ }^{82}$ This provision complies with the Islamic principles as viewed by the Shafie School that minerals resources are not included in right of occupying land as they are for general community at large. ${ }^{83}$ This can be further illustrated when a salt mine was relinquished from occupancy right by the Prophet because it is a natural resource and the person claiming such right has not spent labour on it. ${ }^{84}$

In this way Islam, while perceiving the essential right of the person to claim private land rights, has, in specific fields of action, considered individual possession pointless, futile or harmful to a more noteworthy benefit of society and subsequently favored the guideline of State ownership. An all such property is announced public property. ${ }^{85}$ This principle is deduced from the following saying of the Holy Prophet: Abyaz bin Hammal said:

I went to the Holy Prophet and asked for the grant of salty water in Marb. He agreed but one of the present there said, O Messenger of God, Why are you entrusting him the treasure of salt? After knowing the facts of the case, the Holy Prophet refused to grant me that salty water. ${ }^{86}$

\section{Size of Grant}

The Land Tenure Act 1992 sets a limit of up to eight acres is allocated in respect of lands acquired through a grant of the Minister. ${ }^{87}$ Zanzibar people are also limited to receive one grant of

\footnotetext{
81 Al-Qur'an, Al-Mulk, 67:15.

82 Section 8 (2) (g), Land Tenure Act 1992.

83 Ainul Jaria Maidin and Bashiran Begum Mobarak Ali, iv and xvi.

84 Abu 'Ubayd al-Qasim ibn Sallam, 276. See also Sunan Abu Dawood, Kitab alKharaj, Vol.2, 870.

85 Afzalur Rahman, Economic Doctrines of Islam, (London: Seerah Foundation, 1990), 86.

86 Ibid.

87 Sections 8 (2) (d), 15 (2), 15 (3), 39 (4) and 39 (5), Land Tenure Act 1992.
} 
agricultural land and up to two grants or urban land. ${ }^{88}$ This helps to bring in the concept of stewardship as men in Islam are considered to be partners in water, fire and pasture. ${ }^{89}$

The Land Tenure Act 1992 has discouraged the allocation of large tracts of land which would inevitably lead to being left idle or abandoned. Majority of the Muslim jurists unanimously agree that the size of the land that can be allocated by the Government by a grant of iqta should not exceed beyond the area of the grantee's ability to cultivate..$^{90}$ In Islam, accumulating large tracts of land and leaving them idle or abandoned while the community is essentially in need of the lands is discouraged. ${ }^{91}$

Shafie and Hanbali Schools maintain that in order to grant a land by iqta, the head of State must ensure that the grantee will be capable to develop the land. ${ }^{92}$ It is essential to look at the capability of the grantee, given the fact that land is regarded as common property for the Ummah as a whole. Granting land in a big acreage would therefore lead to injustice among people. ${ }^{93}$

\section{Collective Land}

Hima (collective) land is concentrated in the rural areas of Zanzibar in which a communal or family unit utilise the land jointly. For instance, lands of kijiji (villages), ukoo and tumbo (family ties), mlango (small patrilineal descent group) and diko (fish landing sites) are all under collective ownership and no private ownership of land is much developed in these sites. Hima (collective) lands such as kiambo are recognised since the colonial era as in the case of Sharifu bin Haji bin Fumu and 4 Ors v. The Administrator General of Zanzibar and 3 Ors, ${ }^{94}$ in which the court recognised the kiambo held under African customary tenure which was also influenced by Islamic law of

\footnotetext{
88 Sections 39 (1) and 42 (1), Land Tenure Act 1992.

89 Sunan Abu Dawood, Kitab al-Kharaj, Vol.2, 870.

90 Abu 'Ubayd al-Qasim ibn Sallam, 290.

91 Fauziah Md. Nor, 617.

92 Ibn Qudamah, Abdullah bin Ahmad Ibn Muhammad Al-Mughni, 42 and Abu 'Ubayd al-Qasim ibn Sallam, 290.

93 Ibn Qudamah, 716.

94 (1951) 8 ZLR 290.
} 
inheritance. ${ }^{95}$ The Land Adjudication Act 1990 states that if the recording officer:

"is satisfied that a person ${ }^{96}$ is in occupation of the land and has been in peaceful, opened and uninterrupted occupation thereof, whether under recognized customary law or otherwise, for a period of more than twelve years, the recording officer shall record such person as the occupation of the land". ${ }^{97}$

When the collective land is recognised as a rightful interest following an adjudication carried out under the Land Adjudication Act 1990 and subsequent registration under the Registered Land Act 1990 , the occupiers will have a right of occupancy ${ }^{98}$ which means that their use and occupation is protected and guaranteed by the Government. $^{99}$

Collective system of land can be adjudicated, occupied and registered as per the Land Adjudication Act $1990^{100}$ and Land Tenure Act $1992 .^{101}$

The collective land-ownership system can be traced to the tribal economic structure in which the concept of private ownership of land was not much developed. ${ }^{102}$ Hima land during then was owned by one or more tribe and cultivated or otherwise used for their collective needs. ${ }^{103}$ The hima may often cover a considerable territory shared by several tribes or subdivisions of tribe, for example seven clans of the tribe of Bani Kilab shared rights of the famous Dir'iyyah. ${ }^{104} \mathrm{Hima}$

95 See also the case of Capt. Barton, First Minister of the Zanzibar Government $v$. Mahomed bin Diwani and Msengeni Wadi Shamte (1910) 1 ZLR 335. See also The Government of His Highness the Sultan of Zanzibar v . Vasanji Gokaldas, Administration of the Estate of Damodar Jeram (1903) 1 ZLR 154.

"Person" under Section 2, Land Adjudication Act 1990 includes any corporate body, registered company registered association or society, and any association or community recognised by the adjudication officer or the Court as a unit for the purpose of holding land.

Section 18(1)(a)(iii), Land Adjudication Act 1990.

Section 7(b), Land Tenure Act 1992.

Section 10(1), Land Tenure Act 1992.

Section 18 (1) (a) (iii), Land Adjudication Act 1990.

Section 7 (b), Land Tenure Act 1992.

Siti Mariam Malinumbay, 290.

103 Yaqub Ibn Ibrahim Abu Yusuf, Kitab Al Kharaj, (Qaherah, al-Matba'ah alSalafiah wa Maktabatuha, 1971), 76-77.

104 Muhammad Abdul Mannan, Islamic Economics: Theory and Practice (Cambridge: Hodder and Stoughton - The Islamic Academy, 1986), 99-100. 
system is similar to collective land ownership in which for instance, there are content with common grazing and possibly also with the primitive cultivation of their land without claiming or determining individual ownership. ${ }^{105}$ Hima also underwent changes from exclusive rights of the tribes to the common hima of the Muslims by replacing it with social solidarity. ${ }^{106}$ The Prophet Muhammad (Peace be upon him) granted the hima of Naqi' for the benefit of Muslims, as cattle of the Muslims were used to graze. ${ }^{107}$ The State can preserve hima for social needs but not for private exploitation or individual interest. ${ }^{108}$ Hima is valid only if it is founded for the poor and for the benefit of the ummah. ${ }^{109}$ Hima lands are mainly regulated for the interest of the wider community and not for the benefit of private individuals. ${ }^{110}$

Previously, the Prophet (Peace be upon him) and the Arabs had neither the concept of land ownership nor the individual property. They knew only about the hima land which is kept as a preserve in the collective interest of the community, the benefits are shared among themselves by some agreements. ${ }^{111}$

\section{Ownership of Trees}

Trees are the backbone to agricultural land and these are recognised by the Land Tenure Act 1992 as of having a different character in ownership against the general concept of a right of occupancy. That is, land can be under occupation of one proprietor while the trees within the same land under the ownership of another person. ${ }^{112}$ This type of tree ownership in Islam is reflected in many sayings of the Prophet as for example:

\footnotetext{
105 Abu Ubayd al-Qasim ibn Sallam, 290.

106 Ahmad Sherfuddin, Kitab Al-Amwal: Abu Jafar Ahmad Ibn al-Daudi, (India: Kitab Bhavan, 2006), 61-62

107 As-Shafi'e, Kitab Al-Umm, 94-95.

108 Abu Dawud, Sunan, Kitab al-Kharaj, Chapter fi arzaq al 'Ummal.

109 Al-Mawardi, al-Ahkam al-Sultaniyyah wa al-Wilayah al-Diniyyah, 323.

110، Great Examples of Hima or Protected Areas in the Middle East," Arwa Aburawa, accessed January 22, 2016, http://www.greenprophet.com/2010/09/ examples-of-hima/\#sthash.7gQK923Q.dpuf.

111 Iqbal, 650.

112 Section 19, Land Tenure Act 1992.
} 
Never does a Muslim plant a tree or sow a crop and a bird, human being, or beast eats from it without earning the reward of charity. ${ }^{113}$

If you have a sapling, if you have the time, be certain to plant it, even if Doomsday starts to break forth. ${ }^{114}$

Whoever plants a tree, reward will be recorded for him so long as it produces fruit. ${ }^{115}$

\section{Wakf Land}

Wakf land is devoted by an owner to help the community for religious purposes or to cater for specific matter e.g. public roads or specific person e.g. orphans. ${ }^{116}$ As Zanzibar is a Muslim populated State, wakf are widely practiced and this is proved by the fact that three fourths of the people's land in Zanzibar is wakf. ${ }^{117}$ Wakf lands are regulated in Zanzibar through the Wakf and Trust Commission Act 2007. ${ }^{118}$ The land laws in Zanzibar also recognise wakf lands. ${ }^{119}$

Wakf is a form of a giving to the people for no material gain rather than seeking the pleasure of Allah as described in the Qur-an:

"By no means shall ye attain righteousness unless ye give (freely) of that which ye love; and whatever ye give, of a truth God Knowth it well. ${ }^{120}$

The concept of wakf in Islam is reflected by the Prophet (Peace be upon him) himself when he built a Quba mosque as a wakf

113 Al-Bukhari, Sahih Al-Bukhari, Hadith No.2320. Also cited in Al-Muslim, Sahih Muslim, Hadith No.1553.

114 Abdul Rauf Muhammad Al-Munawi, Fayd al-Qadir Sharh al-Jami' al-Saghir, (Beirut: Dar al-Ma'rifah, 1954), 30.

115 Majma' al-Zawaid, Vol.5, 480.

116 Section 2 Wakf and Trust Commission Act 2007. See also Sharifah Zubaidah Syed Abdul Kader and Nuarrual Hilal Mohd Dahlan, "Current Legal Issues Concerning Awqaf in Malaysia," in Waqf Laws and Management: Reality and Prospects, ed. Abdul Haseeb Ansari, (Kuala Lumpur: IIUM Press, 2011).

117 Mika Torhonen, The Past, Present and Future of Land Tenure in Zanzibar, (London: The Royal Institution of Chartered Surveyors, 1998), 29.

118 Sections 2, 31 and 37, Wakf and Trust Commission Act 2007.

119 Sections 2 and 43 (2), Land Tenure Act 1992; Section 18, Land Adjudication Act 1990 and Sections 2 and 86, Registered Land Act 1990.

120 Al-Qur'an, Al-Imran, 3:92. 
during his flight from Mecca to Madina. ${ }^{121}$ The Prophet (Peace be upon him) also built a second wakf mosque in Madina known as Masjid an-Nabawi. Non-Muslims can also be benefactors and beneficiaries of wakf as for instance, one of the earliest wakf sponsors during the Prophet's time was a Jew named Mukayrid. ${ }^{122}$

Wakf is mainly attributed by a famous report by Ibn Umar who said that his father (Umar) acquired a land at Khaibar. He came to Allah's Apostle (Peace be upon him) and sought his advice in regard to it. He said: Allah's Messenger, I have acquired land in Khaibar. I have never acquired property more valuable for me than this, so what do you command me to do with it? Thereupon he (Allah's Apostle) said: If you like, you may keep the corpus intact and give its produce as Sadaqa. So 'Umar gave it as Sadaqa declaring that property must not be sold or inherited or given away as gift. And Umar devoted it to the poor, to the nearest kin, and to the emancipation of slaves, aired in the way of Allah and guests. ${ }^{123}$ Other practices on wakf by the early generations include: Uthman gave Ruma a well near Al Madina, Ali gave a piece of land at Yanbu, Al Zubair also gave his house in Makkah and another house in Egypt. ${ }^{124}$

\section{Land Registration}

Registration of land is an important element which confers the proprietor a right of occupancy and a guarantee from the Government that the person has secured ownership of land rights and interests as per the laws. No right of occupancy of land in Zanzibar is completed unless registered. ${ }^{125}$ This allows the Government of Zanzibar to make proper land use plans and archiving land ownership in a systematic manner which can be easily accessible for development and land administration purposes.

\footnotetext{
121 Al Samhudi, Wafa' al Wafa bi Akhbar Dar al Mustafa, (1971), 338.

122 Fauziah Md. Nor, 627. See also Bisheh, "The Mosque of the Prophet at Madinah Throughout the First Century A.H. with Special Emphasis on the Umayyad Mosque" (PhD diss., University of Michigan, 1979), 86-95.

123 Al-Muslim, Sahih Muslim, Kitab al-Wasiyyah, The Book of Bequests, Hadith No.4006.

124 "Sharjah Awqaf," Al-Bukhari, accessed June 9, 2016, http://www.awqafshj.gov.ae.

125 Sections 10 and 11, Land Tenure Act 1990. See also Sections 5, 6 and 12 (2) (1), Registered Land Act 1990.
} 
Land registration is a form of covenant or contract between the Government of Zanzibar and the occupier in that rights and conditions of land utilisation are governed under the land title. ${ }^{126}$ In Islam, the owner can gain the title to the land when showing willingness to refrain from Israf, or extravagant spending.

Islamic law places a great deal of emphasis on making agreements into writing which in this includes land registration. ${ }^{128}$ This allows the parties to the land registration title to remain faithful to the terms specified in them, so much so that faithfulness to the terms of contracts is considered a distinguishing characteristic of a Muslim. The Prophet was quoted as saying: "Muslims are bound by their stipulations." When the Prophet was asked about the believer, he replied, "A believer is one with whom the people can trust their persons and possessions." 129

In Zanzibar, no right of occupancy is valid until registered under the Registered Land Act $1990 .{ }^{130}$ Hence, all transactions affecting a right of occupancy must be recorded in the land register within sixty days, from the date of such transaction. ${ }^{131}$ Upon registration of a right of occupancy under the provisions of the Registered Land Act 1990, that interest shall receive the guarantee of the Government as to its regularity and propriety in all of its aspects. ${ }^{132}$

\section{Forfeiture}

The Minister responsible for lands can issue an order for terminating the land when it is being left abandoned or being utilised contrary to the planning rules. ${ }^{133}$ The land shall be designated as abandoned if the holder is not in possession of the land for a period of eighteen months or, in case of agriculture, three growing seasons. ${ }^{134}$ Land shall be designated as idle where the person in possession has failed over a period of two years to use the for the purpose it was allocated,

Section 10(1), Land Tenure Act 1992.

Bashir, 82.

Refer the Al-Qur-an, Baqarah, 2:282 which specify a (loan) deed to be in writing.

Bashir, 82.

Section 8(2)(a), Land Tenure Act 1992.

Section 8(2)(b), Land Tenure Act 1992.

Section 10(1), Land Tenure Act 1992.

Section 58, Land Tenure Act 1992.

Section 59, Land Tenure Act 1992.
} 
maintain or keep such land or buildings in proper and productive use and repaid. ${ }^{135}$ The rules on abandoned and idle land allows proper utilisation of land, as land is scarce and the demand to it are higher, generally speaking in a situation of Zanzibar which is highly populated.

Islamic principles explicitly states that possessed land shall be not left undeveloped. The Prophet disapproved of leaving productive assets (land) idle and urged those who owned land to cultivate it or leave it to those who could do so. ${ }^{136}$ Also recorded that the Prophet said that: "If anyone has land, he should cultivate it or lend it to his brother." (Reported by Al-Bukhari and Muslim). ${ }^{137}$ Another narration is by Caliph Umar bin Abdul-Aziz who issued a decree to all concerned saying, "Let out your land for one-third, one-fourth, onefifth and up to one-tenth of the yield, but do not leave the land uncultivated." $" 138$

In the case of forfeiture, no compensation is paid as the person himself failed to make use of the land. This is proved in the case of the land in Wadi Aqiq granted to Bilal bin Harith. ${ }^{139}$

\section{Termination of Private Land for National Interest}

The Government of Zanzibar is permitted to terminate any right of occupancy on grounds of public, subject to it being proved before a Court of competent jurisdiction that clear and convincing reasons exist for the repossession of such right of occupancy. ${ }^{140}$ In addition, the Government of Zanzibar is under duty to pay market value compensation for the land and any unexhausted improvements thereon. ${ }^{141}$ Termination can be further elaborated to be a justifiable

Centenary of the Torrens System in Malaysia," eds. Judith Sihombing, Malayan

Law Journal (1989).

140 Section 56 (a), Land Tenure Act 1992.

141 Article 17 (b), Constitution of Zanzibar 1984. See also Section 56 (b), Land

Tenure Act 1992.

Bashir, 81.

Yusuf al-Qardawi, The Lawful and the Prohibited in Islam, (Pakistan: Al-Falah Foundation, 1960), 275.

Yusuf al-Qardawi, 276.
} 
means for defence, security of the people, health requirement and town planning. ${ }^{142}$

Land termination in Islam is referred to as ta'mim which is a mechanism for the State to fulfill the needs of the nations as per maslahah 'ammah (public interest) ${ }^{143}$ Background of terminating land rights through acquisition in Islam can be traced back to the case of the people of Bajeela. ${ }^{144}$ The land of Bajeela was acquired by Caliph Umar on reason of a better form of land administration which will benefit the community at large. In Islam, the State is given discretion to terminate and repossess the land only where the land is not utilised or the land is required by the State for public purposes. ${ }^{145}$

Compensation follows when land is acquired by the State. This is paid for the development and efforts done on the land, since land belongs to Allah. As for instance, Caliph 'Umar paid handsome prices to the Jews for their lands in Fida, Khaibar and Wadi al-Qura. ${ }^{146}$ Liberal compensation was also paid to Christians of Najran and Yaman which was either in cash or in the form of equivalent land. ${ }^{147}$ Caliph Umar also acquired land from Muslims e.g. Jarir ibn Abdullah Bajeela's land was acquired to the State as it was deemed necessary for the public. ${ }^{148}$ Eighty dinars from the public treasury (bait-ul-mal) was paid to Jarir. ${ }^{149}$

Normally when land is compulsorily acquired for public purposes, then compensation is paid to 'all those who are effected irrespective of their beliefs. ${ }^{150}$ Acquiring of land for public purpose must however be handled with care as the State may incur the wrath of Allah. ${ }^{151}$ Land administration must therefore balance the needs of

142

150

151

Article 17 (a), Constitution of Zanzibar 1984.

See Al-Majalla al-Ahkam al-Adaliyyah, 1876, Book VIII, Chapter I, Section II. See also Afzalur Rahman, Economic Doctrines of Islam.

Schacht, 142.

Naved, Umar's Rule, (New Delhi: Anmol Publications Pvt. Ltd, 2010), 237.

Fauziah Md. Nor, 625.

Naved, 237.

Sayyid Abu A'la Mawdudi, in First Principles of Islamic Economics, ed. Khurshid Ahmad, (London: Kube Publishing Ltd, 2013), 122. See also Ainul Jaria Maidin and Bashiran Begum Mobarak Ali, viii.

Ben Shemesh, Yahya bin Adam's Kitab al-Kharaj, (Netherlands: Brill, 1967), 35 .

Ainul Jaria Maidin and Bashiran Begum Mobarak Ali, viii.

Ibid, ix. 
all persons who have a right or interest in the land while exercising the duty of compulsorily acquire land for public purposes. ${ }^{152}$

\section{Land Vested in the President of Zanzibar}

Land in Zanzibar is considered to be owned absolutely by the Government, through the President's vesting: "public land is declared to be vested in, and at the disposition of the President, to be held by him". ${ }^{153}$ This provision reflects the first President's statement that 'trees are yours, the land is ours'. ${ }^{154}$ Recommendations made by Land Policy of $1982^{155}$ and repealed laws explicitly states that ownership of all land in Zanzibar is under the Government. ${ }^{156}$ In addition, the Land Policy Draft of 2012 expressly states that 'all land shall be owned by the Government'. ${ }^{157}$ The Land Policy Draft 2012 tries to mirror the duties of the Department of Lands which has to regulate land use, planning and development with the reflection that all land is considered to be government land. ${ }^{158}$

Though, the Land Tenure may have specified that land is vested by the President for the people which brings in the principle of vicegerent found in Islam, but the question still stands that the President or Government is not held accountable by any person if it goes against the principles of vicegerent or stewardship in Islam. As for Islam, the concept of all land is vested absolutely in Allah which

152 Elvan Syaputra et al., "Maslahah as an Islamic Source and its Application in Financial Transaction," Journal of Research in Humanities and Social Science 2, no.5 (2014): 68. The International Institute of Islamic Thought, Ibn Ashur Treatise on Maqasid al-Shari'ah, (London: IIIT, 2006), 92. Fakhr al-Din alRazi, al-Mahsul fi ușul al-fiqh, (Memor: Yale University). Al-Mahsul fì ilm ușūl al-fiqh, ed. Taha Jabir Fayyad al-Alwani (Riyadh: Jami'at al-Imam Muhammad bin Saud, 1980), 218. Al-Ghazali, al-Mustasfa min 'ilm al-usul, (Baghdad: Muthanna, 1970), 286-87. See also Muhammad Khalid Masud, Shatibi's Philosophy of Islamic Law, (Kuala Lumpur: Islamic Book Trust, 1995), 139. Imran Ahsan Khan Nyazee, Theories of Islamic Law: The Methodology of Ijtihad, (Kuala Lumpur: The Other Press, 1994), 322. Section 3 (2), Land Tenure Act 1992. Middleton, Land Tenure in Zanzibar, 77. Saad Yahya and Associates, Land Policy for Zanzibar and Pemba, (Zanzibar: Zanzibar Revolutionary Government, 1982), 43. Public Land Decree 1921 and Government Land Decree 1965.

Ministry of Lands, Housing, Water and Energy, Zanzibar Land Policy Draft, 2012, 17.

158 Department of Lands, "Land Tenure in Zanzibar: A Review of the Land Tenure Act of 1992," Zanzibar, n.d. 
also brings with it the concept of accountability. It makes land being wisely utilised, not in a wasteful or damaging manner by those holding trust over land. ${ }^{159}$ Holding the land by the government in absolute terms without a safeguard of accountability is different to Islamic principles as the "The earth belongs to Allah..." Allah belongs all things in the heavens and on the earth..."

\section{Interests and Charges}

Several provisions in the land laws freely permit the usury or 'riba' practices. Usury is related under the land laws as 'charge' which resembles to interest and this is mainly linked to financial transactions such as mortgaged properties. ${ }^{162}$ Interests, usury or riba are practices which are contrary to Islamic principles as described:

But God hath permitted trade and forbidden usury. ${ }^{163}$

And if you do not, then be informed of a war (against you) from Allah and His Messenger. But if you repent, you may have your principal - (thus) you do no wrong, nor are you wronged. ${ }^{164}$

$\mathrm{O}$ you who believe, do not consume your property among yourselves wrongfully, but let there be trade by mutual consent... ${ }^{165}$

The Prophet declared war on usury and those who deal in it; he pointed out its dangers to society, saying, When usury and fornication appear in a community, the people of that community render themselves deserving of the punishment of Allah. (Reported by al-Hakim; Abu Y'ala has reported something similar on good authority).

Interest represents a source of unjustified advantage. Instead, Muslims are required to apply profit at an unspecified rate of return in

Siti Mariam Malinumbay, 302.

Al-Qur'an, Al-Araf, 7:128.

Al-Qur'an, An-Nisa, 4:132.

162 Sections 2, 12, 13 and 14, Land Tenure Act 1992; Section 2 Part V - Division 3, Registered Land Act 1990. See also Rule 17, Land Transfer Regulations 2011.

163 Qur'an, Al-Baqarah, 2:275.

164 Qur'an, Al-Baqarah, 2:279.

165 Qur'an, An-Nisa, 4:29.
} 
substitute to usury. ${ }^{166}$ The central restriction of the Islamic financial transactions is on riba (interest). According to the above citations, mortgages and the like described under the land laws of Zanzibar resembles to a form of riba. Interests and charges represent a source of unjustified advantage, and those who deal with riba wage war against God and His Apostle. ${ }^{167}$ A system based on profit-and-risk sharing is believed to be more equitable than a system based on interest and usury. ${ }^{168}$

\section{Monopoly and Hoarding of Land}

There is no limit to the maximum size of a person holding land in Zanzibar, except for land being allocated on grants by the Minister. ${ }^{169}$ This provision impliedly accepts monopolisation of land by few welloff people who can buy of whatever size of land and at the end leaving the land idle or abandoned, while the community at large is actually in need of the land.

Though freedom for individual and natural competition in the marketplace is guaranteed by Islam, it nevertheless condemns those who, driven by ambition and greed, accumulate land at the expense of others and become rich by manipulation. ${ }^{170}$ Islamic law does not encourage ... large tracts of land to be monopolised under few peoples which would inevitably lead to the lands being left idle and abandoned. Majority of Muslim jurists unanimously agree that the size of the land ... should not exceed beyond the area of the [person's] ability to cultivate. ${ }^{171}$

People in Zanzibar additionally make use of the monopolisation for future gain in that the value of the land increases by time. This is surely a practice of hoarding which has been restricted in Islam: "The man who hoards goods is evil..." ${ }^{172}$ Land in Islam should not be monopolised in the hands of a few as it will create chaos and social imbalance. Shari'ah requires land to be distributed to all rather than being confined to a few wealthy people as stated I the Qur-an: "And

\footnotetext{
166 Bashir, 75.

167 Ibid, 75.

168 Ibid, 76.

169 Section 15(1), Land Tenure Act 1992.

170 Yusuf al-Qardawi, The Lawful and the Prohibited in Islam, 254.

171 Fauziah Md. Nor, 617.

172 Yusuf al-Qardawi, The Lawful and the Prohibited in Islam, 255.
} 
spend (in charity) out of the (substance) whereof He has made you heirs." 173 Also, narrated by M'aqal bin Yassar, a companion of the Prophet, I heard the Messenger of Allah say, 'Whoever interferes with the prices of the Muslims' goods in order to raise them deserves that Allah should make him sit in the Fire on the Day of Resurrection.' "Did you hear this from Allah's Messenger?" asked 'Ubaidullah, and M'aqal replied, "More than once or twice" (Reported by Ahmad and al-Tabarani).

\section{Land Confiscation}

The land confiscation from 1965-1972 where aimed to distribute land to the many poor peoples as well as strengthening economic development through agriculture. However, the practices of confiscation were attributed to corruption, land grabbing, force evacuation and non-compensation. ${ }^{174}$ The Confiscation of Immovable Decree No.8 of 1964 and Public Land Decree No.13 of 1965 directly stated that compensation has to be paid, though they were in principal not paid. ${ }^{175}$ The confiscation system during that time worked very well, as nobody questioned the government to confiscate private land rights or non-compensation. ${ }^{176}$ The confiscation manners though characterized with ill practices and yet the law regulating them have been repealed, are still considered to be valid to "no matter what procedures were used. ${ }^{177}$

The practices of land confiscation in Zanzibar are contrary to Islam as observed in the Qur-an: "O ye who believe! Eat not up your property among yourselves in vanities." 178 In addition, any compulsory acquisition of private land for public purposes whether through termination, purchase or confiscation has been unanimously agreed by Muslim jurists that the Government should pay

\footnotetext{
173 Al-Qur'an, Al-Hadid, 57:7. Shivam Goel, Concept of Rights in Islam, (Germany: Lambert Academic Publishing, 2014), 16.

174 Torhonen, 35.

175 Ali Hassan, "Land Adjudication in Zanzibar: Legal Problems and Prospects" (LL.B Research, University of Dar es Salaam, 1997) 25.

176 Saad Yahya and Associates, 26-27.

177 Section 4, Land Tenure Act 1992.

178 Al-Qur'an, An-Nisa, 4:29.
} 
compensation to the land owner. ${ }^{179}$ In general terms, land acquired through unjustifiable means such as gharar (speculation), maysir (gambling), bribing, stealing, cheating or illegal trading is forbidden. Land used for certain commercial practices e.g. intoxication and prostitution are also haram (prohibited). ${ }^{180}$

The use of land and ownership in Islam is therefore restricted by the prohibition of interests, charges, monopoly and hoarding of land and non-compensation for compulsory acquisition. ${ }^{181}$ The objectives of Shari'ah pertain to this world and to the hereafter. The concept of accountability is therefore brought in and people cannot evade responsibility of utilising the land in a stewardship manner. ${ }^{182}$ With the dictates and prohibitions of the Shari'ah, complying stewardship is motivated through the Qur-an by promising an eternal reward or exemplifying a punishment. ${ }^{183}$

179 Article 1216, Al-Majalla al-Ahkam al-Adaliyyah, permits acquisition for road in return for compensating the deprived land owner. Article 1216 of the Majallah reads: "When necessary, the property of any person held in absolute ownership may be taken for its value by order of the authorities and made part of the road. He may not be deprived of ownership thereof, however, until he has been paid the price".

180 There are two ahadith recorded by Imam Bukhari in a Chapter bearing the title: "The sin of him who usurps the land of others', clearly condemns usurpation: Allah's Apostle said "Whoever usurps the land of somebody unjustly, his neck will be encircled with it down the seven earths (on the day of Resurrection", AlBukhari, Vol. III, Book XLII, The Book of Luqaa: A Well-Tied Punch or Purse or Lost of Things Picked up by Somebody, Hadith No. 632 and Abu Salama narrated that there was a dispute between him and some people (about a piece of land). When he told Aisha about it, she said: "O Abu Salama! Avoid taking the land unjustly, for the Prophet said: "Whoever usurps one span of the land of somebody, his neck will be encircled down the seven earths." Al-Bukhari, Vol. III, Book XLII, The Book of Luqaa: A Well-Tied Punch or Purse or Lost of Things Picked up by Somebody, hadith No. 633. Both ahadith apply equally to government acquisition or private party encroachments. See Raj Bhala, 516-517. Bashir, 72.

182 Ibid, 73.

183 Asyraf Wajdi Dusuki and Nurdianawati Irwani Abdullah, "Maqasid alShariyah, Maslahah, and Corporate Social Responsibility," The American Journal of Islamic Social Sciences, 24, no.1 (2007): 32. 


\section{CONCLUSION}

The land tenure legislation in Zanzibar is compatible with the Islamic principles of public land, mawat and ihya (dead land and revival of dead land), iqta (land allocation or grant), provisional right of occupancy, right of occupancy, no occupancy to mineral lands, size of grant, hima (collective land), ownership of trees, wakf land, land registration, forfeiture, ta'mim (termination of land for national interest). Zanzibar land tenure is, without doubt, influenced with Islamic principles.

To a large extent, Zanzibar land tenure laws are compatible with Islamic principles. However, there are some provisions in the legislation which are contrary to Islam. These include land being vested in the President, interests and charges, monopoly and hoarding of land and land confiscation. Having a population of more than $95 \%$ Muslims, it is possible to introduce the remaining significant elements of Islamic principles within the land tenure laws.

For the purposes of dropping the legislative provisions permitting interests and making the laws compatible with Islamic principles, it would be of benefit to adjust the land tenure legislative provisions permitting charges and interests laws to interest free or profit and loss sharing principles. The challenges on monopolisation and hoarding are to be regulated on a stewardship and vicegerent principles. Also, for the purpose of holding the government accountable, it is recommended that the ownership of land by the government to remain as a trustee. Confiscation problems can be settled with the laws of equity, justice and reconciliation. As a word of caution, a complete legal reform is not recommended, as it is possible to deal with the challenges, on a step-by-step basis. 